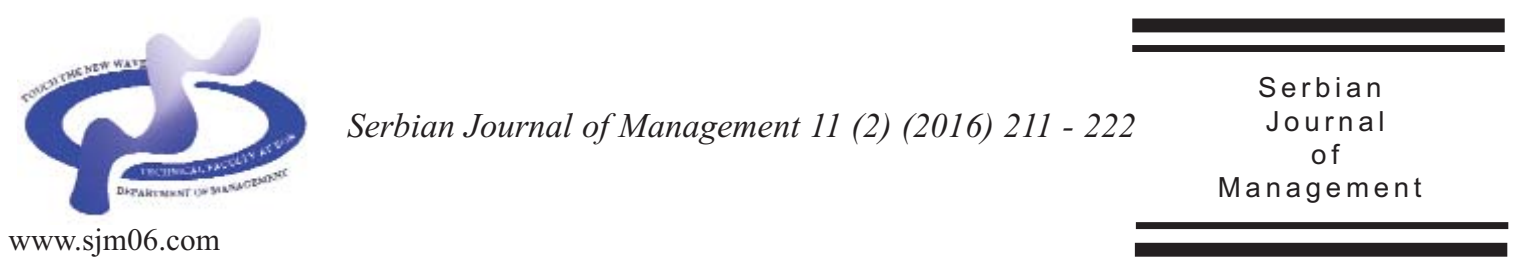

\title{
A ROBUST BI-OBJECTIVE UNCERTAIN GREEN SUPPLY CHAIN NETWORK MANAGEMENT
}

\author{
Hêriş Golpîra* \\ Department of Industrial Engineering, Snanadaj Branch, Islamic Azad University, \\ Sanandaj, Iran
}

(Received 12 April 2016; accepted 22 June 2016)

\begin{abstract}
Conflicting objectives becomes a common issue in many supply chain network optimization problems. In this paper, a new model is formulated to design a green supply chain network through a new mixed integer linear programming problem. Uncertain demand and stochastic environmental respect levels are the main parameters of the formulation. The first objective function minimizes the cost of the supply chain while the second objective function minimizes $\mathrm{CO}_{2}$ emission. Conditional Value at Risk (CVaR) approach is adapted to deal with demand uncertainty and the stochastic $\mathrm{CO}_{2}$ emission level. Finally, the model outputs and its results discussion are illustrated through a numerical example.
\end{abstract}

Keywords: Green supply chain, conditional value at risk, uncertainty, stochastic programming, robust optimization

\section{INTRODUCTION}

Nowadays, environmental concern becomes a crucial global issue. Green Supply Chain (GrSC) is an effective approach to deal with this significant global attitude (Golpîra et al., In Press). Thus, Green Supply Chain Network Design (GrSCND) becomes very important area for both practitioners and researchers (Coskun et al., 2016). That is, it not only reduces negative environmental impacts, but also enhances the competitiveness of companies (Wu et al., 2015). In this paper, a new model is formulated to design a Green Supply Chain Network (GrSCN) through a robust bi-objective programming.

Jamshidi et al. (2012), proposed a multi-

\footnotetext{
* Corresponding author: herishgolpira@gmail.com
}

DOI:10.5937/sjm11-10705 
objective GrSC optimization, however, the approaches and the contributions were quite different. The proposed study formulates the problem under uncertain environment, which makes the proposed method more realistic. Rather than the impact of $\mathrm{CO}_{2}$ emission in the network upstream, the demand uncertainty and the retailers' risk averseness are addressed in the proposed model. To do these, a bi-objective mathematical programming is formulated in order to design a multi-tiered single product GrSCN. Environmental protection investment and fixed production, alliance, and transportation costs are considered in the first objective function while, second objective function is used to handle the environmental aspects. To the best our knowledge, there is no similar research to address this collaboration incorporated with the risk averseness of retailers and stochastic $\mathrm{CO}_{2}$ emission level only in the network upstream. Reformulation of the second objective function makes the model analytically solvable. The main contributions of this paper are as follows:

a) Formulating a new robust GrSCND problem in compliance with retailers' risk averseness and stochastic $\mathrm{CO}_{2}$ emission level is the main contribution of the paper.

b) Integrating stochastic environmental parameters with risk management results in a new method in the area of Green Supply Chain Network Design Problem (GrSCNDP).

The rest of the paper is as follows: The mathematical formulation will be described in section 2 with details. Model formulation and solution approach will be pointed out in section 3. Computational results will be presented in section 4 and finally, conclusions will be presented in section 5 .

\section{LITERATURE REVIEW}

According to the extensive review, reported by Seuring (2013); Brandenburg et al. (2014); El bounjimi et al. (2014); Gunasekaran et al. (2015); Eskandarpour et al. (2015), some more recent close researches are studied as follows. Feng et al. (2014) investigated a Closed-Loop Supply Chain Network Design Problem (CLSCNDP), regarding the demand uncertainty. Talaei et al. (2016) examined a facility location/allocation model for the same problem with collection/inspection, manufacturing/remanufacturing, and disposal centers through a robust fuzzy programming approach. Garg et al. (2015) formulated a CLSCNDP through a biobjective nonlinear integer programming approach and leveraged interactive multiobjective programming to solve the model. Soleimani and Kannan (2015) formulated a new CLSCNDP given both the design and the planning decision variables. They solved their model by a new hybrid meta-heuristic algorithm. Mallidis et al. (2014) analized the impact of GrSCND and inventory optimization problem in a Supply Chain Network (SCN). Gui-tao et al. (2014) introduced a SCNDP considering the customers' price rigidities in compliance with the manufacturers' risk awareness. Sharifzadeh et al. (2015) designed a biofule SCN subject to seasonal and geographical uncertainties, throughout a Mixed Integer Programming (MIP) problem. Coskun et al. (2016) considered customers' green expectations in a new GrSCNDP. Kawasaki et al. (2015) proposed a GrSCNDP via multicriteria decision making methods for the lead times, costs and $\mathrm{CO}_{2}$ emissions. Rezaee et al. (2015) proposed the same GrSCNDP in a 
carbon trading environment through a twostage stochastic programming approach. Demand uncertainty and SCN responsiveness under different carbon policies are successfully addressed in the model proposed by Martś et al. (2015). Kagawa et al. (2015) analyzed the importance of the $\mathrm{CO}_{2}$ emissions in Global Supply Chain Network (GSCN). Dotoli et al. (2015) rated the candidates companies in each tier of SCN, using the cross-efficiency Data Envelopment Analysis (DEA) in fuzzy environment. Kannegiesser et al. (2015) tried to minimize the time to sustainability parameter in a SCND problem. Urata et al. (2015) balanced the costs and the $\mathrm{CO}_{2}$ emmision volumes via a MIP approach. Golpîra et al. (2015) investigated the same problem using multi-objective mathematical programming and the $\mathrm{CO}_{2}$ emmission in all of the tiers of the network. Concidering the greenness in the last tier of the network, in their research, may reduce the importance of the parameter risk averseness. Miret et al. (2016) formulated a biomass SCNDP via multi-objective optimization approah, considering all sustainable development dimensions. Chibeles-Martins et al. (2016) formulated a mixed integer linear multiobjective programming model for GrSCNDP and solved it throughout a meta-heuristic algorithm based on Simulated Annealing (SA) approach. Nakamichi et al. (2016) estimated the cost and $\mathrm{CO}_{2}$ emission with a sustainable SCN in a Thailand automobile industry. Nouira et al. (2016) investigated the impacts of a carbon emission-sensitive demand on SCNDP and examined their model in a textile industry.

This paper formulates a new robust GrSCNDP in compliance with stochastic $\mathrm{CO}_{2}$ emission level and retailers' risk averseness in the network last tier. The proposed method and Gui-tao et al. (2014) have the same methodology to deal with the risk averseness parameter. But, Gui-tao et al. (2014) considered the risk averseness of the manufacturer, whereas the proposed model is based on the risk averseness of the network demand side. Li et al. (2014) investigated a SCN designation with risk averse retailer and risk natural manufacturer. They considered single objective dualchannel SCND with no attention to greenness attitude. Also, Rezaee et al. (2015) considered the same idea regarding uncertain demand and environmental investment, but they reached different results. This paper not only considers the uncertain demand and stochastic level of $\mathrm{CO}_{2}$ emission, but also reflects the risk averseness of the network, simultaneously.

\section{PROBLEM DESCRIPTION, FORMULATION AND SOLUTION}

The problem consists of several companies to produce a single product in a multi-tiered GrSCN. Uncertain demand and retailers' risk awareness are considered in the model. The first objective function contains of fixed alliances set-up costs, environmental protection investment, and transportation and manufacturing costs. Holding and shortage costs are not assumed in the model in order to achieve simpler model. Consumer relationship is allowed in the last echelon for the SCN. Thus, the demand uncertainty affects the SCN directly from this tier. The following notation for the model formulation is described: 
$l \in L \quad$ set of scenarios for the environmental respects level

$a \in A \quad$ set of operations

$i \in I \quad$ set of potential companies available for tier $a$

$j \in J \quad$ set of potential companies available for tier $a+1$

$(i, j) \in \Gamma \quad$ set of available alliances

$v \in V \quad$ set of environmental protection level

$I_{a} \quad$ number candidates in tier $a$

$\eta_{i, a, j, a+1} \quad$ fixed cost of linking candidate $i$ in tier $a$ to candidate $j$ in tier $a+1$

$\vartheta_{i, a, v} \quad$ fixed environmental protection investment at candidate $i$ in tier $a$ according to environmental protection level $v$

$\tau_{i, a, j, a+1} \quad$ transportation unit cost from candidate $i$ in tier $a$ to candidate $j$ in tier $a+1$

$\xi_{i, a} \quad$ unit processing cost at candidate $i$ in tier $a$

$q_{i, a} \quad$ the environmental protection level of candidate $i$ in tier $a$

$s_{l}{ }^{-} \quad$ under-achievement of the goal regarding the environmental respects level $l$

$s_{l}^{+} \quad$ supper-achievement of the goal regarding the environmental respects level $l$

$\psi \quad$ a very large number

$\phi \quad$ unit penalty cost, assigned to control the level of $\mathrm{CO}_{2}$ emission

$\alpha \quad$ risk averseness of the DM

$\varepsilon \quad$ adequately small number as a penalty for the $s^{-}$

$\tilde{\Delta} \quad$ uncertain amount of total $\mathrm{CO}_{2}$ emission level in all the SC!

$\chi_{i, a, v} \quad$ per-unit environmental influence in facility $i$ in tier $a_{\text {at level }} v$

$\pi_{i, a, j, a+1} \quad$ amount of $\mathrm{CO}_{2}$ emission for the $\operatorname{arc} i, a, j, a+1$

$\tilde{d} \quad$ uncertain demand

$x_{i, a, j, a+1} \quad$ amount of product shipped from candidate $i$ in tier $a$ to candidate $j$ in tier $a+1$

$z_{i, a} \quad$ amount of product manufactured at candidate $i$ in tier $a$

$y_{i, a, j, a+1}= \begin{cases}1 & \text { if relation between member } i \text { in tier } a \text { and member } j \text { in tier } a+1 \text { is included } \\ 0 & \text { otherwise }\end{cases}$

$\omega_{i, a}= \begin{cases}1 & \text { if candidate }{ }^{i} \text { in tier } a \text { is included in the chain } \\ 0 & \text { otherwise }\end{cases}$

$q_{i, a, v}= \begin{cases}1 & \text { if the environmental protection } v \text { is selected } \\ 0 & \text { otherwise }\end{cases}$ 
The bi-objective mixed integer linear described as follows: programming formulation of the model is

$$
\begin{aligned}
& \Theta=\min \sum_{a=1}^{\varphi} \sum_{j=1}^{I_{a+1} \sum_{i=1}^{I} a} \eta_{i, a, j, a+1} y_{i, a, j, a+1}+\sum_{a=1}^{\varphi} \sum_{i=1}^{I_{a}} \xi_{i, a} z_{i, a}+\sum_{a=1}^{\varphi} \sum_{j=1}^{I_{a+1}} \sum_{i=1}^{I_{a}} \tau_{i, a, j, a+1} x_{i, a, j, a+1}+\sum_{a=1}^{\varphi-1} \sum_{i=1}^{I_{a}} \sum_{v=0}^{V} \vartheta_{i, a, v} q_{i, a, v} \\
& \Theta^{\prime}=\min \sum_{a=1}^{\varphi-1} \sum_{i=1}^{I_{a}} z_{i, a} \sum_{v=0}^{V} \chi_{i, a, v}+\sum_{a=1}^{\varphi-1} \sum_{i=1}^{I} \sum_{j=1}^{I_{a+1}} \pi_{i, a, j, a+1} x_{i, a, j, a+1}
\end{aligned}
$$

Subject to:

$$
\begin{aligned}
& \sum_{v=0}^{V} q_{i(a) v}-1 \leq 0, \quad i \in I, a \in A, \\
& \sum_{i=1}^{I} \omega_{i(a)}-1=0, \quad a \in A, \\
& \omega_{i, a} \geq y_{i, a, j, a+1}, \quad \forall(i, j) \in \Gamma, a \in A, \\
& \omega_{j, a+1} \geq y_{i, a, j, a+1}, \quad \forall(i, j) \in \Gamma, a \in A, \\
& \omega_{i, a}+\omega_{j, a+1} \leq y_{i, a, j, a+1}+1, \quad \forall(i, j) \in \Gamma, a \in A, \\
& \omega_{i, a}-\sum_{v=1}^{V} q_{i, a, v}=0 \quad, i \in I, a \in A, \\
& \omega_{i, a} \times \psi \geq \sum_{j=1}^{I a+1} x_{i, a, j, a+1}, \quad i \in I, a \in A, \\
& \omega_{j, a+1} \times \psi \geq \sum_{i=1}^{I_{a}} x_{i, a, j, a+1}, \quad j \in J \quad a \in A, \\
& \sum_{j=1}^{I} x_{i, a, j, a+1}=z_{i, a}, \quad i \in I, \quad a \in A \\
& \omega_{i, a} \times \tilde{d} \leq z_{i, a}, \quad i \in I, \quad a \in A, \\
& x_{i, a, j, a+1} \geq 0, \quad \forall(i, j) \in \Gamma, a \in A, \\
& q_{i, a, v} \in\{0,1\}, \quad i \in I, \quad a \in A, \quad v \in V \\
& y_{i, a, j, a+1} \in\{0,1\}, \quad \forall(i, j) \in \Gamma, \quad a \in A, \\
& \omega_{i, a} \in\{0,1\}, \quad i \in I, \quad a \in A .
\end{aligned}
$$


Equation (1) defines total cost of the network while, facility-depending and linkage-depending $\mathrm{CO} 2$ emission are integrated into related variables in Equation (2). By constraint (3) the final SCN selects only one environmental level for each selected company. Constraints (4)-(7), ensure that the final network holds only one company a tier, and Constraint (8) selects the environmental level only from the opening alternatives. By Constraints (9) and (10), the production is performed only through the designed network, balanced by Constraints (11). Constraint (12) is to build the link between $z_{i, a}$ and $w_{i, a}$ while, the type of the variables are defined by Constraints (13) to (16).

To solve the problem, the goal programming approach is adopted to the model with uncertain right hand side value, illustrated in Equation (17).

$\sum_{a=1}^{\varphi-1} \sum_{i=1}^{I} z_{i, a} \sum_{v=0}^{V} \chi_{i, a, v}+\sum_{a=1}^{\varphi-1} \sum_{i=1}^{I} \sum_{j=1}^{I_{a+1}} \pi_{i, a, j, a+1} x_{i, a, j, a+1}-\tilde{\Delta}=0$ (21): deal with demand uncertainty is to remove the best realizations of the data and optimize the problem over the remaining data as a robust optimization against downside risk, introduced by Bertsimas and Brown (2009). To do this, the conditional expectation $E\left[X \mid X \leq q_{\alpha}(X)\right]$ is used in Equation (20), where $q_{\alpha}(X)$ is the $\alpha$-quantile of the random variable $X$.

$q_{\alpha}(X)=\inf \{x \mid P(X \leq x) \geq \alpha\}, \alpha \in(0,1)$

The presented problem in this paper is the minimization, so the cases with the lowest costs are removed and the tail expectation $E\left[X \mid X \geq q_{\alpha}(X)\right]$ is considered. A nonparametric estimator of the $E\left[X \mid X \geq q_{\alpha}(X)\right]$ is presented in Equation

$\mathrm{I}_{\alpha}=1 / N \sum_{\alpha}^{I} \sum_{k=1} X_{(k)}$,

Considering scenario based approach to deal with the model, transforms Equation (1) and Equation (17) to Equation (18) and Equation (19) respectively:

where $N$ is the number of in-hand realizations, $N_{\alpha}$ is the number of remaining cases after trimming to the retailers' risk

$\Theta=\min \sum_{a=1}^{\varphi} \sum_{j=1}^{I_{a+1}} \sum_{i=1}^{\frac{I}{a}} \eta_{i, a, j, a+1} y_{i, a, j, a+1}+\sum_{a=1}^{\varphi} \sum_{i=1}^{I_{a}} \xi_{i, a} z_{i, a}+\sum_{a=1}^{\varphi} \sum_{j=1}^{I_{a+1}} \sum_{i=1}^{\frac{I}{a}} \tau_{i, a, j, a+1} x_{i, a, j, a+1}+$

$\sum_{a=1}^{\rho-1} \sum_{i=1}^{I_{a}} \sum_{v=0}^{V} \vartheta_{i, a, v} q_{i, a, v}+\sum_{l=1}^{L} \varsigma_{l}\left(\frac{s_{l}^{+}+s_{l}^{-}}{r}\right)$

Subject to:

$\sum_{a=1}^{\varphi-1} \sum_{i=1}^{I_{a}} z_{i, a} \sum_{v=0}^{V} \chi_{i, a, v}^{l}+\sum_{a=1}^{\varphi-1} \sum_{i=1}^{I_{a}} \sum_{j=1}^{I_{a+1}} \pi_{i, a, j, a+1}^{l} x_{i, a, j, a+1}-\Delta_{l}+s_{l}^{-}-s_{l}^{+}=0, \quad l=1, \ldots, L$

where $r$ is the range of the objective function, assigned only to avoid any scaling problem.

The idea that is employed in this paper to $\alpha\left(N_{\alpha}=\lfloor N \cdot(1-\alpha)+\alpha\rfloor \approx N \cdot(1-\alpha)\right)$ 
and $X_{(k)}$ is the $k$-th smallest component of $\left(X_{1}, \ldots X_{N}\right)$. In the presented problem, $X_{(k)}$ will be defined as the $k$-th greatest component.

The $E\left[X \mid X \geq q_{\alpha}(X)\right]$ is finally referred as the Conditional Value-at-Risk (CVaR) which is, in this paper, employed to deal with the demand uncertainty. So, the reformulation of Equation (12) is as follows:

$z_{i(\varphi)} \geq \beta\left(\frac{1}{s_{1-\alpha}} \sum_{s=1}^{\left\lfloor s_{1-\alpha}\right\rfloor} d_{(s)}-\left(\frac{s_{1-\alpha}-\left\lfloor s_{1-\alpha}\right\rfloor}{\left\lfloor s_{1-\alpha}\right\rfloor}\right) d_{\left(\left\lceil s_{1-\alpha}\right\rceil\right)}\right) \cdot w_{i(\varphi)}, \quad i=1,2, \ldots, I_{\varphi}$,

\section{COMPUTATIONAL RESULTS AND SENSITIVITY ANALYSIS}

Figure 1 illustrates the problem of a 4-tier network, with 3 potential candidates in each tier and 4 levels of environmental protection for each candidate. Each node of echelon $i(i=1,2,3)$ is concerned with a node in echelon $j(j=i+1)$, which yields to $12^{3} \times 3$ $=5184$ feasible routes altogether. A numerical example is established based on the randomly generated data, revealed in Table 1. Table 2, includes additional data for numerical example, built to study the

effectiveness of the model. "Unif" in Table 2 stands for uniform distribution. The resulted problem can be solved by CPLEX 11.0 on a $\mathrm{PC}$ that has a $2.20 \mathrm{GHz}$ Intel(R) Core(TM)2 Duo CPU and 3.0G RAM. The results are shown in Table 3.
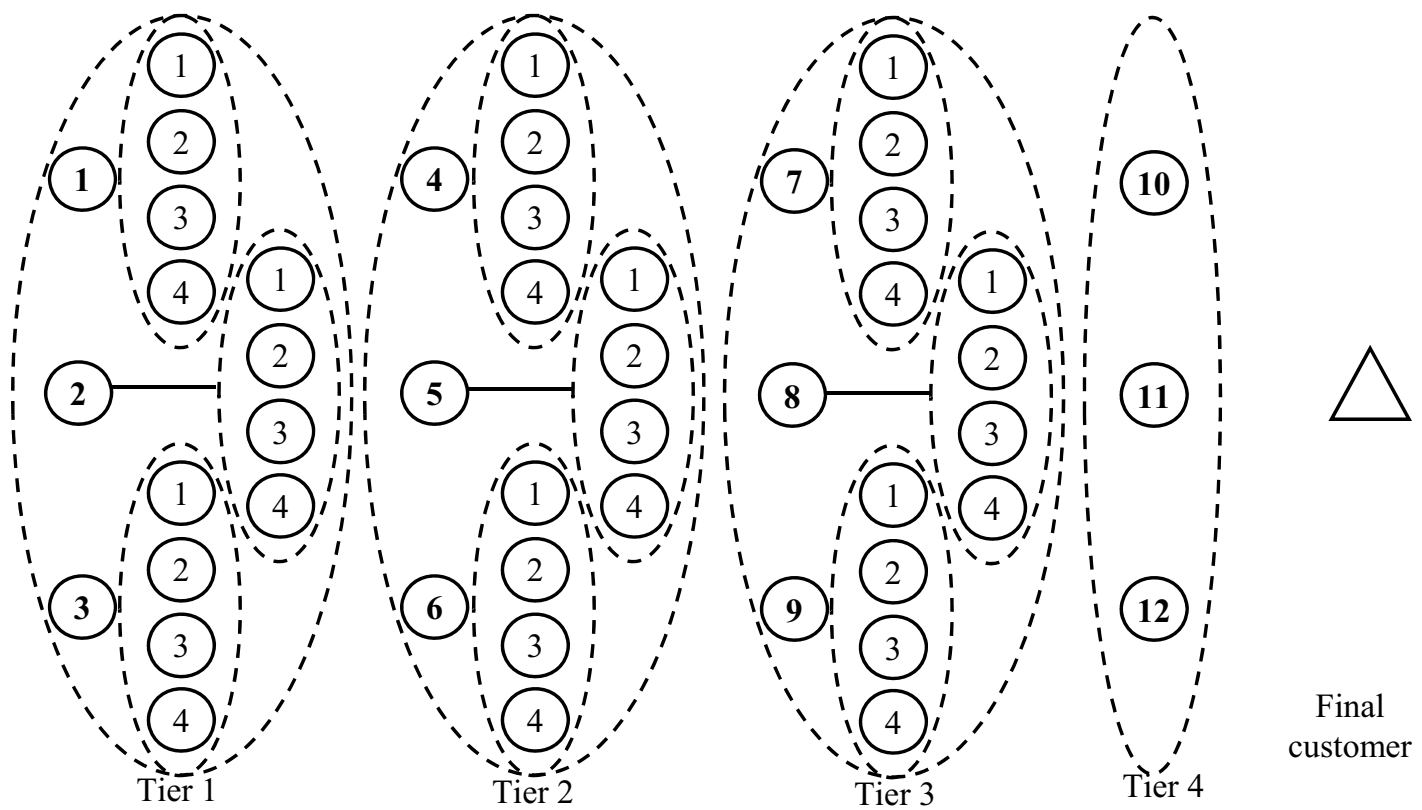

Final customer

Figure 1. SCN for the example

Table 1. Scenarios

\begin{tabular}{cc}
\hline Scenario probability & Value of the environmental respects \\
\hline 0.35 & 145000 \\
0.45 & 150000 \\
0.20 & 160000 \\
\hline
\end{tabular}


Table 2. Data used in the problem

\begin{tabular}{ll}
\hline Data type & Range \\
\hline Uncertain demand & Unif $(50,500)$ \\
Transportation unit cost & Unif $(10,15)$ \\
Fixed alliance cost & Unif $(1000,5000)$ \\
Production unit cost & Unif $(20,60)$ \\
Fixed environmental protection investment & Unif $(100,300)$ \\
\hline
\end{tabular}

Table 3. Results of computational study

\begin{tabular}{|c|c|c|c|c|c|c|}
\hline$\alpha$ & $1-\alpha$ & Expected cost & $\begin{array}{c}\text { Located facilities } \\
\text { (environmental level) }\end{array}$ & Chain performance & $\begin{array}{c}\text { Cost } \\
\text { variability }\end{array}$ & $\begin{array}{l}\text { Percent cost } \\
\text { variability }\end{array}$ \\
\hline 0.99 & 0.01 & 15206.61 & $2(4)-4(1)-7(1)-12$ & $100 \%$ & - & \\
\hline 0.98 & 0.02 & 15160.37 & $2(4)-4(1)-7(1)-12$ & $100 \%$ & 44.30 & $0.29 \%$ \\
\hline 0.97 & 0.03 & 15158.15 & $2(4)-4(1)-7(1)-12$ & $100 \%$ & 2.12 & $0.01 \%$ \\
\hline 0.96 & 0.04 & 15001.93 & $2(4)-4(1)-7(1)-12$ & $100 \%$ & 149.65 & $1.00 \%$ \\
\hline 0.95 & 0.05 & 14937.33 & $2(4)-4(1)-7(1)-12$ & $100 \%$ & 61.87 & $0.41 \%$ \\
\hline 0.94 & 0.06 & 14900.38 & $\begin{array}{l}2(4)-4(1)-7(1)-12 \\
2(4)-4(1)-7(1)-10\end{array}$ & $\begin{array}{l}095 \% \\
005 \%\end{array}$ & 35.40 & $0.24 \%$ \\
\hline 0.93 & 0.07 & $\begin{array}{l}14781.05 \\
14628.05\end{array}$ & $\begin{array}{l}2(4)-4(1)-7(1)-12 \\
2(4)-4(1)-7(1)-10\end{array}$ & $\begin{array}{l}094 \% \\
006 \%\end{array}$ & 114.30 & $0.77 \%$ \\
\hline 0.92 & 0.08 & $\begin{array}{l}14536.82 \\
14628.05\end{array}$ & $\begin{array}{l}2(4)-4(1)-7(1)-12 \\
2(4)-4(1)-7(1)-10\end{array}$ & $\begin{array}{l}093 \% \\
007 \%\end{array}$ & 146.56 & $1.00 \%$ \\
\hline 0.91 & 0.09 & $\begin{array}{l}12897.18 \\
14781.05\end{array}$ & $\begin{array}{l}2(4)-4(1)-7(1)-12 \\
2(4)-4(1)-7(1)-10\end{array}$ & $\begin{array}{l}091 \% \\
009 \%\end{array}$ & 87.39 & $0.60 \%$ \\
\hline 0.90 & 0.10 & $\begin{array}{l}14628.05 \\
14536.82\end{array}$ & $\begin{array}{l}2(4)-4(1)-7(1)-12 \\
2(4)-4(1)-7(1)-10 \\
2(4)-4(1)-8(1)-11\end{array}$ & $\begin{array}{l}091 \% \\
009 \% \\
030 \%\end{array}$ & 92.10 & $0.63 \%$ \\
\hline 0.70 & 0.30 & 14628.05 & $\begin{array}{l}2(4)-4(1)-7(1)-12 \\
2(4)-4(1)-8(1)-12 \\
2(4)-4(1)-9(1)-12\end{array}$ & $\begin{array}{l}055 \% \\
015 \% \\
005 \%\end{array}$ & & \\
\hline 0.50 & 0.50 & 11994.1 & $\begin{array}{l}2(4)-4(1)-8(1)-11 \\
2(4)-4(1)-7(1)-11 \\
2(4)-4(1)-8(1)-12\end{array}$ & $\begin{array}{l}040 \% \\
055 \% \\
015 \%\end{array}$ & $\vdots$ & $\vdots$ \\
\hline 0.40 & 0.60 & 11399.66 & $\begin{array}{l}2(4)-4(1)-8(1)-11 \\
2(4)-4(1)-7(1)-11\end{array}$ & $\begin{array}{l}040 \% \\
045 \%\end{array}$ & & \\
\hline 0.10 & 0.90 & 8725.123 & $\begin{array}{l}2(4)-4(1)-9(1)-12 \\
2(4)-4(1)-8(1)-11\end{array}$ & $\begin{array}{l}092 \% \\
008 \%\end{array}$ & - & - \\
\hline 0.09 & 0.91 & 8619.607 & $\begin{array}{l}2(4)-4(1)-9(1)-12 \\
2(4)-4(1)-8(1)-11\end{array}$ & $\begin{array}{l}099 \% \\
001 \%\end{array}$ & 32.30 & $0.37 \%$ \\
\hline 0.08 & 0.92 & 8554.123 & $2(4)-4(1)-9(1)-12$ & $100 \%$ & 62.73 & $0.73 \%$ \\
\hline 0.07 & 0.93 & 8541.802 & $2(4)-4(1)-9(1)-12$ & $100 \%$ & 11.80 & $0.14 \%$ \\
\hline 0.06 & 0.94 & 8510.072 & $2(4)-4(1)-9(1)-12$ & $100 \%$ & 30.40 & $0.36 \%$ \\
\hline 0.05 & 0.95 & 8505.474 & $2(4)-4(1)-9(1)-12$ & $100 \%$ & 4.40 & $0.05 \%$ \\
\hline 0.04 & 0.96 & 8452.749 & $2(4)-4(1)-9(1)-12$ & $100 \%$ & 50.50 & $0.60 \%$ \\
\hline 0.03 & 0.97 & 8375.115 & $2(4)-4(1)-9(1)-12$ & $100 \%$ & 74.36 & $0.89 \%$ \\
\hline 0.02 & 0.98 & 8317.421 & $2(4)-4(1)-9(1)-12$ & $100 \%$ & 55.26 & $0.66 \%$ \\
\hline 0.01 & 0.99 & 8313.099 & $\begin{array}{l}2(4)-4(1)-9(1)-12 \\
\text { Results average }\end{array}$ & $100 \%$ & $\begin{array}{c}4.14 \\
\mathbf{5 8 . 8 5}\end{array}$ & $\begin{array}{l}0.05 \% \\
\mathbf{0 . 4 9 \%}\end{array}$ \\
\hline
\end{tabular}


The results show that the retailer's level of risk averseness has a significant impact on the final network designation. According to Table 3 , it is inferred that by increasing the level of risk averseness, the expected cost is increased. It is obvious that there are only four deigned chains from all of 5184 possible ones. This may validate the model regarding the model robustness. That is, Mulvey et al. (1995) defined the model robustness as the situation in which the model remains "almost" feasible for all the scenarios. Table 3 reveals that chain 2(4)-4(1)-7(1)-12 is optimal for the large value of alpha and it has been substituted by the chain 2(4)-4(1)-9(1)12 as the value of the parameter alpha decreases. Furthermore, the low cost variability with respect to the level of alpha makes the solution to be robust. Because Mulvey et al. (1995) defined the solution robustness as the remaining of the problem solution "close" to optimal for all of the scenarios. Finally, although Natarajan et al. (2009) set the alpha level to 0.99 or 0.95 , Table 3 demonstrates the solution and the model robustness in the extended alpha range.

\section{CONCLUSION}

This paper investigates the single product GrSCNDP. The CVaR approach is successfully addressed in the formulated biobjective mathematical programming to report the retailers' risk averseness in the last tier of the network. The model also reflects the effect of $\mathrm{CO}_{2}$ emission level in the SCN upstream as well as the demand uncertainty in its' downstream. The capability of the model to consider demand uncertainty, stochastic $\mathrm{CO}_{2}$ emission level, and the risk attitude of the retailer is the superiority of the model. The research found that the level of retailers' risk averseness has a significant impact on the GrSCND. Moreover, using the CVaR approach to deal with uncertainty of the demand in GrSCNDP, leads to robustness. Our numerical experiment simplifies the sensitivity analysis of the model to the parameter.

For practicing managers, there are some helpful information, may be found in the paper dealing with day-to-day motivational problems. Lack of information may clearly be inferred from practice especially in SCNs which contain several companies and marketplaces. The criticality of this uncertain situation is intensified regarding new products introduction from the SCN. According to the novelty of the product, the risk averseness of the retailer becomes a critical parameter in marketing. The model may be useful in such a situation because it makes robust decision which is valid for all the scenarios in such an uncertain environment. Greenness as the other important concept, addressed in the paper, is the crucial issue especially in the area of the car production, energy supply and the food supply networks. In addition, there are many practical real world examples which are using the retailers risk attitude in GrSCND problems. Fashion retailers, such as Zara, H\&M, Mango and Top Shot try to be risk averse and green in order to achieve business success. The importance of green agricultural supply chain management in risky environment and policy-makers' risk aversion is also reported by some researchers such as Dwyer (2013). 


\title{
РОБУСТНО БИ-ОБЈЕКТНО УПРАВЉАЊЕ ЕКОЛОШКИМ
} ЛАНЦИМА СНАБДЕВАЊА

\author{
Hêriş Golpîra
}

\section{Извод}

Конфликти међу циљевима постају чест фактор код оптимизације многих ланаца снабдевања. У овом раду, формулисан је нови модел дизајна мреже еколошких ланаца снабдевања, кроз нови проблем линеарног планирања заснован на миксу целих бројева. Основни параметри формулације су неизвесност потражње и стохастичко понашање окружења. Прва функција циља минимизира трошкове ланца снабдевања, док друга функција циља минимизира емисију $\mathrm{CO}_{2}$. Приступ условне вредности ризика (CVaR) је прилагођен да би се анализирала неизвесност потражње и стохастички ниво емисије $\mathrm{CO}_{2}$. На крају рада, излаз модела и дискусија резултата су илустровани преко нумеричког примера.

Кључне речи: Еколошки ланци снабдевања, условна вредност ризика, неизвесност, стохастичко програмирање, робустна оптимизација

\section{References}

Bertsimas, D., \& Brown, D. B. (2009). Constructing uncertainty sets for robust linear optimization. Operations Research, 57 (6), 1483-1495.

Brandenburg, M., Govindan, K., Sarkis, J., \& Seuring, S. (2014). Quantitative models for sustainable supply chain management: Developments and directions. European Journal of Operational Research, 233 (2), 299-312.

Chibeles-Martins, N., Pinto-Varela, T., Barbosa-Púvoa, A.P., \& Novais, A.Q. (2016). A multi-objective meta-heuristic approach for the design and planning of green supply chains-MBSA. Expert Systems with Applications, 47, 71-84.

Coskun, S., Ozgur, L., Polat, O., \& Gungor, A. (2016). A model proposal for green supply chain network design based on consumer segmentation. Journal of Cleaner
Production, 110, 149-157.

Dotoli, M., Epicoco, N., \& Falagario, M. (2015). A Technique for Supply Chain Network Design under Uncertainty using Cross-Efficiency Fuzzy Data Envelopment Analysis. IFAC-PapersOnLine, 48 (3), 634639.

Dwyer, J. (2013). Transformation for sustainable agriculture: what role for the second Pillar of CAP? Bio-based and Applied Economics, 2 (1), 29-47.

El bounjimi, M., Abdulnour, G., \& AitKadi, D. (2014). Green Closed-Loop Supply Chain Network Design: A Literature Review. International Journal of Operations and Logistics Management, 3 (4), 275-286.

Eskandarpour, M., Dejax, P., Miemczyk, J., \& Přton, O. (2015). Sustainable supply chain network design: An optimizationoriented review. Omega, 54, 11-32.

Feng, Z., Wang, Z., \& Chen, Y. (2014). The equilibrium of closed-loop supply chain supernetwork with time-dependent parameters. Transportation Research Part E: 
Logistics and Transportation Review, 64, 111.

Garg, K., Kannan, D., Diabat, A., \& Jha, P. (2015). A multi-criteria optimization approach to manage environmental issues in closed loop supply chain network design. Journal of Cleaner Production, 100, 297-314.

Golpîra, H., Zandieh, M., Najafi, E., \& Sadi-Nezhad, S. (2015). Coordination of green supply chain network, considering uncertain demand and stochastic $\mathrm{CO}_{2}$ emission level. Journal of Industrial Engineering and Management Studies, 2 (2), 43-54.

Golpîra, H., Zandieh, M., Najafi, E., \& Sadi-Nezhad, S. (In Press). A multiobjective multi-echelon green supply chain network design problem with risk-averse retailers in an uncertain environment. Scientia Iranica: Transaction on Industrial Engineering.

Gui-tao, Z., Hao, S., \& Jin-song, H. (2014). Research on supply chain network equilibrium problem with multi-type suppliers. Paper presented at the Service Systems and Service Management (ICSSSM), 2014 11th International Conference on Service Systems and Service Management.

Gunasekaran, A., Subramanian, N., \& Rahman, S. (2015). Green supply chain collaboration and incentives: Current trends and future directions. Transportation Research Part E: Logistics and Transportation Review, 74, 1-10.

Jamshidi, R., Ghomi, S.F., \& Karimi, B. (2012). Multi-objective green supply chain optimization with a new hybrid memetic algorithm using the Taguchi method. Scientia Iranica, 19 (6), 1876-1886.

Kagawa, S., Suh, S., Hubacek, K., Wiedmann, T., Nansai, K., \& Minx, J. (2015). CO 2 emission clusters within global supply chain networks: Implications for climate change mitigation. Global Environmental Change, 35, 486-496.

Kannegiesser, M., Gżnther, H.-O., \& Autenrieb, N. (2015). The time-tosustainability optimization strategy for sustainable supply network design. Journal of Cleaner Production, 108, 451-463.

Kawasaki, T., Yamada, T., Itsubo, N., \& Inoue, M. (2015). Multi Criteria Simulation Model for Lead Times, Costs and CO2 Emissions in a Low-carbon Supply Chain Network. Procedia CIRP, 26, 329-334.

Li, B., Chen, P., Li, Q., \& Wang, W. (2014). Dual-channel supply chain pricing decisions with a risk-averse retailer. International Journal of Production Research, 52 (23), 7132-7147.

Mallidis, I., Vlachos, D., Iakovou, E., \& Dekker, R. (2014). Design and planning for green global supply chains under periodic review replenishment policies. Transportation Research Part E: Logistics and Transportation Review, 72, 210-235.

Martś, J. M.C., Tancrez, J.-S., \& Seifert, R.W. (2015). Carbon footprint and responsiveness trade-offs in supply chain network design. International Journal of Production Economics, 166, 129-142.

Miret, C., Chazara, P., Montastruc, L., Negny, S., \& Domenech, S. (2016). Design of bioethanol green supply chain: Comparison between first and second generation biomass concerning economic, environmental and social criteria. Computers \& Chemical Engineering, 85, 16-35.

Mulvey, J.M., Vanderbei, R.J., \& Zenios, S.A. (1995). Robust optimization of largescale systems. Operations research, 43 (2), 264-281.

Nakamichi, K., Hanaoka, S., \& Kawahara, Y. (2016). Estimation of cost and CO 2 emissions with a sustainable cross- 
border supply chain in the automobile industry: A case study of Thailand and neighboring countries. Transportation Research Part D: Transport and Environment, 43, 158-168.

Natarajan, K., Pachamanova, D., \& Sim, M. (2009). Constructing risk measures from uncertainty sets. Operations research, 57 (5), 1129-1141.

Nouira, I., Hammami, R., Frein, Y., \& Temponi, C. (2016). Design of forward supply chains: Impact of a carbon emissionssensitive demand. International Journal of Production Economics, 173, 80-98.

Rezaee, A., Dehghanian, F., Fahimnia, B., \& Beamon, B. (2015). Green supply chain network design with stochastic demand and carbon price. Annals of Operations Research, 1-23.

Seuring, S. (2013). A review of modeling approaches for sustainable supply chain management. Decision Support Systems, 54 (4), 1513-1520.

Sharifzadeh, M., Garcia, M.C., \& Shah, N. (2015). Supply chain network design and operation: Systematic decision-making for centralized, distributed, and mobile biofuel production using mixed integer linear programming (MILP) under uncertainty. Biomass and Bioenergy, 81, 401-414.

Soleimani, H., \& Kannan, G. (2015). A hybrid particle swarm optimization and genetic algorithm for closed-loop supply chain network design in large-scale networks. Applied Mathematical Modelling, 39 (14), 3990-4012.

Talaei, M., Moghaddam, B.F., Pishvaee, M.S., Bozorgi-Amiri, A., \& Gholamnejad, S. (2016). A robust fuzzy optimization model for carbon-efficient closed-loop supply chain network design problem: a numerical illustration in electronics industry. Journal of Cleaner Production, 113, 662-673.
Urata, T., Yamada, T., Itsubo, N., \& Inoue, M. (2015). Modeling and Balancing for Costs and $\mathrm{CO}_{2}$ Emissions in Global Supply Chain Network among Asian Countries. Procedia CIRP, 26, 664-669.

Wu, K.-J., Liao, C.-J., Tseng, M.-L., \& Chiu, A.S. (2015). Exploring decisive factors in green supply chain practices under uncertainty. International Journal of Production Economics, 159, 147-157. 